\title{
TÖBBFOTONOS REZONANCIA-FOKOZOTT IONIZÁCIÓBAN KILÉPŐ ELEKTRONOK DINAMIKUS INTERFERENCIÁJA
}

\author{
Szabó Krisztián ${ }^{1}$, Csehi András ${ }^{1}$ \\ ${ }^{1}$ Debreceni Egyetem, Elméleti Fizikai Tanszék, 4026 Debrecen Bem tér 18, Magyarország \\ DOI: https://doi.org/10.14232/kvantumelektronika.9.31
}

\section{Bevezetés}

Alapállapotú atomok és molekulák lézerrel történő ionizációja során kilépő elektronok kinetikus energiáját (amennyiben a $\hbar \omega$ foton energia nagyobb mint az $I_{p}$ ionizációs potenciál) az $E=n \cdot \hbar \omega-I_{p}$ Einstein-féle összefüggés adja meg. A rendszer által elnyelt fotonok számának (n) növekedtével ún. ATI (above treshold ionization = küszöb feletti ionizáció) csúcsok sorozatát figyelhetjük meg a kiváltott elektronok energia spektrumában. Az első ATI csúcs nominális pozíciója a spektrumban $\hbar \omega-I_{p}$, míg a magasabb rendủ csúcsoké ehhez képest egy-egy foton energiával eltolva figyelhető meg. A csúcsok magassága erősen csökken az elnyelt fotonok számának növekedtével tükrözvén azt, hogy a magasabb rendü ionizációs folyamatok jelentősen kisebb valószínüséggel következnek be.

Az eddig elmondottak gyenge terek esetén érvényesek. Intenzív lézerek alkalmazásával egyrészt jelentősen megnő a többfotonos folyamatok valószínüsége, másrészt a kötött és kontinum energia szintek Stark-eltolódása miatt a fenti Einstein-féle összefüggés módosul, ami az ATI csúcsok pozíciójának megváltozását eredményezi.

A közelmúltban több kutatócsoport tagjai is rámutattak arra, hogy erős lézertérbe helyezett atomok és molekulák fotoelektron spektrumában egy küszöb lézer intenzitás felett az intenzitás növelésével a spektrumbeli csúcsok újfajta, egyre gazdagodó struktúrát mutatnak [1-6]. Az egyszerü fotocsúcsokon megjelenő interferencia mintázatért az alkalmazott lézerpulzus felszálló és leszálló ágában ionizált elektronok interferenciája a felelős [2]. Erős lézerpulzusok esetén (amennyiben azok többciklusúak) a rendszer energia szintjei és ezáltal az emittált elektronok energiái is időtől függő Stark-eltolódást szenvednek, melyek időlefolyását a pulzus intenzitás burkolója, nagyságát pedig a lézer intenzitása határozza meg. Erős terek esetén tehát az ionizáció folyamatában az elektronok energiája időben a pulzus intenzitás burkolója szerint változik, ezáltal pedig a pulzus felszálló és leszálló felében kibocsájtott elektronok pontosan azonos energiákkal rendelkeznek. Az azonos energiájú elektronok különböző idöben emittálódnak ami a megfigyelt energia spektrumban interferencia megjelenéséhez vezet (innen a dinamikus interferencia elnevezés [2]).

A dinamikus interferenciát a keletkezés mechanizmusa szerint két alapvető csoportra oszthatjuk: i) direkt egyfotonos ionizációban ( $\hbar \omega>I_{p}$ ) létrejövő [1-4], valamint ii) köztes rezonáns állapotokon keresztül végbemenő $\left(\hbar \omega<I_{p}\right)$ ionizáció során keletkező dinamikus interferenciát [5-6] különböztethetünk meg. Az utóbbi esetben legalább két foton szükséges a rendszer ionizációjához. Az első foton a rendszer két kötött állapota között Rabi-oszcillációt indukál, a második foton pedig az éppen gerjesztett állapotban lévő elektronokat ionizálja. Az íly módon kilépő elektronok mikroszkópikus szondaként fontos információval szolgálnak az adott Rabi-átmenetről [5].

Jelen munkában ultragyors intenzív lézerpulzus segítségével egy atomi rendszer többfotonos ionizációját tanulmányozzuk. A rendszer két kötött állapota között két foton segítségével Rabioszcillációt indukálunk, amit aztán egy harmadik ionizáló fotonnal szondázunk. Ezen $2+1$ fotonos ún. REMPI (resonance-enhanced multiphoton ionization $=$ rezonancia-fokozott többfotonos 
ionizáció) folyamatban a kétfotonos gerjesztés révén olyan átmeneteket tanulmányozhatunk melyek dipólrendben (egy fotonnal) tiltottak. Többfotonos átmenetekben az állapotok jelentős Starkeltolódást szenvednek (ellenben a dipól átmenetekkel, ahol ez elhanyagolható [5]) aminek fontos következményi vannak az emittált elektronok energia eloszlásában. Be fogjuk látni, hogy a 2+1 fotonos REMPI folyamatban megfigyelt fotoelektron spektrum erös dinamikus interferencia mintázatot mutat, melynek alakját alapvetően meghatározza a rezonánsan csatolt kötött állapotok Stark-eltolódása. Rávilágítunk arra, hogy az 1+1 REMPI folyamattal szemben [5] a kétfoton átmenetet követő ionizációban a spektrum erös aszimmetriát mutat a felhasadás és eltolódás mellett. Kvalitatív analízisünkben a numerikusan egzakt hullámfüggvény propagálási eredményeinket egy három állapotú modellel összevetve megmutatjuk, hogy a Stark-eltolódások valamint a kétfoton Rabi-frekvencia pontosan hogyan határozza meg a spektrum jellemzőit.

\section{Eredmények}

Numerikus vizsgálatunk eredményeit egy, az erős terü fizikában gyakran alkalmazott egydimenziós Coulomb modell atom [7] példáján szemléltetjük. Az atom-lézer kölcsönhatás leírásához az i $\hbar d \psi / d t=\left[\hat{H}_{0}+\hat{V}(t)\right] \psi$ időtől függő Schrödenger-egyenletet oldjuk meg az operátorok szétválasztásán alapuló ún. SOT (split operator technique) módszer segítségével [8]. $\hat{H}_{0}$ a perturbálatlan atom Hamilton-operátora, $\hat{V}(t)=-\vec{E}(t) \cdot \vec{\mu}$ pedig a lézer-atom kölcsönhatási tag dipól közelítésben. $E(t)=E_{0} \cdot e^{-t^{2} / 2 \tau^{2}} \cdot \cos (\omega t)$ alakú x irányban lineárisan poláros Gauss lézerpulzusokat alkalmazunk a vizsgált $2+1$ fotonos rezonancia-fokozott többfotonos ionizáció kiváltásához, melyek tipikus pulzushossza $\tau=20 \mathrm{fs}$, intenzitása pedig az $I_{0}=10^{12} \mathrm{~W} / \mathrm{cm}^{2}-7 \times 10^{13} \mathrm{~W} / \mathrm{cm}^{2}$ tartományba esik. A lézer központi frekvenciáját úgy választjuk meg, hogy az kétfoton rezonánsan csatolja a kezdeti $\mid \mathrm{I}>$ alapállapotot és egy gerjesztett $\mid \mathrm{R}>$ állapotot (1.ábra(a)), melyek között a kiválasztási szabály tiltja az egyfotonos átmenetet $(\mu=0)$. Az itt vizsgált egyelektronos modell atom esetén konkrétan az alap- és második gerjesztett állapotokat csatoljuk kétfoton rezonánsan $\omega=5.25 \mathrm{eV}$ körfrekvenciájú lézer segítségével ( $\hbar=1$ atomi mérték rendszerben) de természetesen más állapotpárok is választhatók lennének.

Ahogy az 1.ábra c) panelén látható, az alkalmazott lézerpulzus aktuális paraméterei mellett a kezdetben alapállapotú atom négy Rabi-oszcillációt végez két foton abszorpciójával és emittálásával az $\mid \mathrm{I}>$ és $\mid \mathrm{R}>$ állapotok között (kis mértékben a szomszédos 1-es és 3-as állapotok is populálódnak). Mindeközben az atom fokozatosan ionizálódik (zöld görbe, 1.ábra(c)). Az ionizált elektronok további fotonok elnyelése révén mind nagyobb energiára tesznek szert, amit jól szemléltet a spektrumban megjelenő egymástól $\omega$ távolságra lévő ATI csúcsok sorozata (1.ábra(b)). Az 1.ábra c) panelén szereplő elektronállapoti betöltöttségek (populáció) a teljes időfüggő propagált hullámfüggvénynek $(\psi(x, t))$ az adott sajátállapotra történő projekciójával számolhatók ( pop $\left._{i}=\left|\left\langle\psi \mid \psi_{i}\right\rangle\right|^{2}\right)$. Az 1.ábra b) panelén látható fotoelektron spektrumot szintén a teljes időfüggő hullámfüggvényből származtathatjuk annak Fourier-transzformációjával (Spektrum $=|F T(\psi)|^{2}$ ).

Közelebbről nézve a spektrumot látható, hogy az ATI csúcsok azonos szerkezettel rendelkeznek, további interferencia mintázatot mutatnak. Az erős lézer hatására kialakuló dinamikus interferencia mintázatban négy kisebb csúcs figyelhető meg, továbbá az is látható, hogy a fő ATI csúcsok bal oldala magasabb mint a jobb oldal, valamint a fö csúcsok pozíciója a kisebb energiák felé tolódik a nominális pozícióhoz képest. Mindezekre a magyarázatot egy három állapotú minimális modell segítségével megadhatjuk, melyet lentebb mutatunk be. 

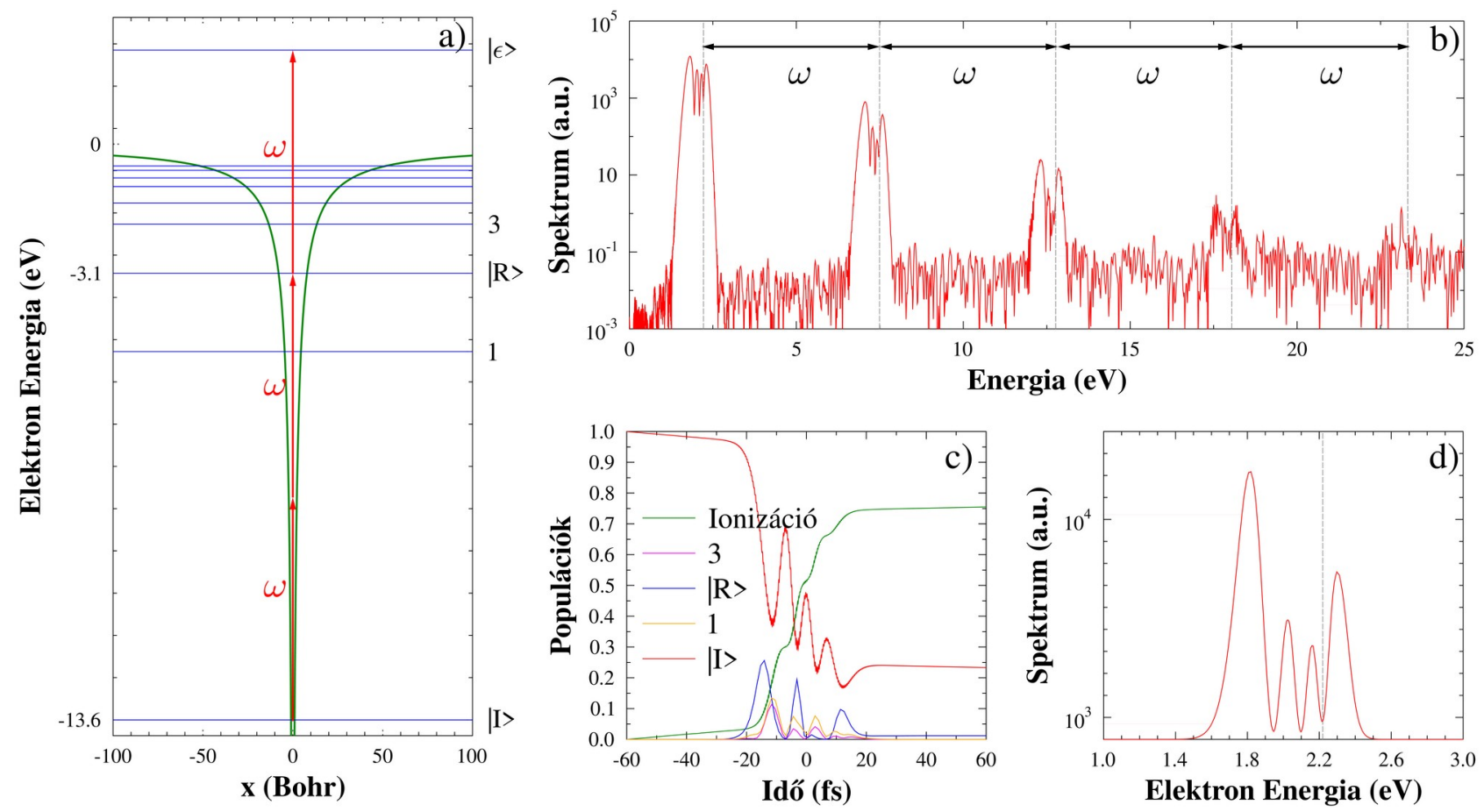

1.ábra (a) Alapállapotú atom többfotonos rezonancia-fokozott ionizációja. Kétfotonos gerjesztéssel az alap- és második gerjesztett állapotok között kiváltott Rabi-oszcillációt követően egy újabb foton elnyelésével a rendszer ionizálódik. (b) További fotonok elnyelése magasabb ATI csúcsok sorozatát eredményezi a spektrumban, melyek egy küszöb lézer intenzitás felett dinamikus interferencia mintázatot mutatnak. (c) A bemutatott példában a rendszer négy Rabi-oszcillációt végez, és (d) ennek megfelelően a spektrumban négy csúcs alakul ki. Az alkalmazott lézer paraméterek: $\tau=20 \mathrm{fs}$, $\omega=5.25 \mathrm{eV}, I_{0}=6.1 \times 10^{13} \mathrm{~W} / \mathrm{cm}^{2}$.

Az 1.ábrán mutatott konvergált spektrum számolása kihívást jelentő feladat még egydimenziós Coulomb modell atomok esetén is. Az interferencia mintázat megörzése érdekében a teljes $\psi(x, t)$ hullámfüggvényre szükség van, ezért elnyelő potenciálok nem alkalmazhatók a rács szélein. Következésképpen óriási térbeli rácson kell megoldani a Schrödinger-egyenletet annak érdekében, hogy a pulzus ideje alatt ionizált elektronok ne érhessék el a rács széleit, elkerülve ezáltal a zavaró reflexiót és transzmissziót. Az itt tekintett $\tau=20 f s$ pulzushossz esetén a szükséges rácsméret a 15000 bohr tartományba esik, a $\psi(x, t)$ megfelelő pontosságú reprezentálásához pedig $\mathrm{kb} .10^{5} \mathrm{db}$ rácspontra van szükség. Minél gyorsabb elektronokat (magasabb ATI csúcsokat) szeretnénk pontosan leírni, annál nagyobb rácsot és több rácspontot kell tekintenünk, ami jelentősen megnehezíti a dinamikus interferencia mintázat pontos leírását.

Az interferencia mintázatban mutatkozó aszimmetria (pl. első ATI csúcs, 1.ábra(d)) pontosabb megértése érdekében az egyszerüség kedvéért ezt követően csak az első ATI csúccsal foglalkozunk. Vizsgáljuk meg mi történik ha a lézer intenzitását fokozatosan növeljük abban a tartományban ahol elöször megjelenik majd tovább erősödik az interferencia mintázat. A kapott eredményeket a 2.ábra mutatja. Itt az a) panelen az látható, hogy $\mathrm{I}_{0}$ növelésével az atom egyre több kétfotonos Rabioszcillációt végez az $\mid \mathrm{I}>$ és $\mid \mathrm{R}>$ állapotok között. A pulzus utáni végső populációk tanúsága szerint az első teljes Rabi-ciklust $I_{0}=1.5 \times 10^{13} \mathrm{~W} / \mathrm{cm}^{2}$-en teljesíti a rendszer, amit aztán továbbiak követnek. A függőleges szaggatott vonalakkal jelölt lézer intenzitásokon számolt spektrumokat a 2.ábra b) panelének bal oldalán láthatjuk a propagált hullámfüggvényből számolva. Látható, hogy a Rabi-oszcillációk számának növekedtével együtt növekszik a spektrumbeli csúcsok száma is: egy 
Rabi-ciklus esetén egy csúcsot, kettő Rabi-ciklus esetén két csúcsot stb. kapunk. Az is megfigyelhető, hogy a spektrum pozíciója kisebb energiák felé eltolódik, valamint az ATI csúcs szétnyílása az $\mathrm{I}_{0}$ növelésével fokozódik.

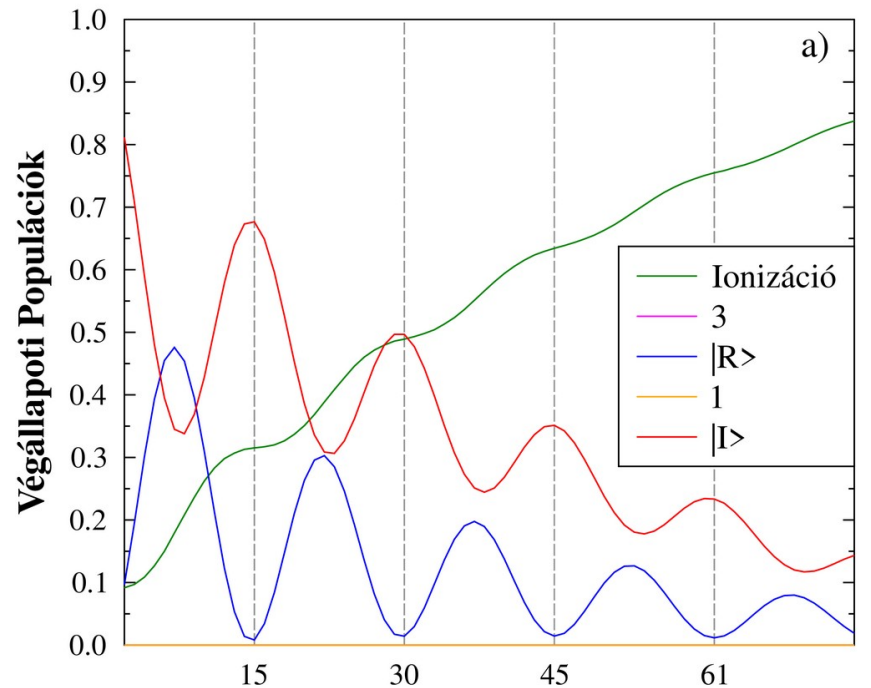

Lézer Intenzitás, $I_{0}\left(10^{12} \mathrm{~W} / \mathrm{cm}^{2}\right)$

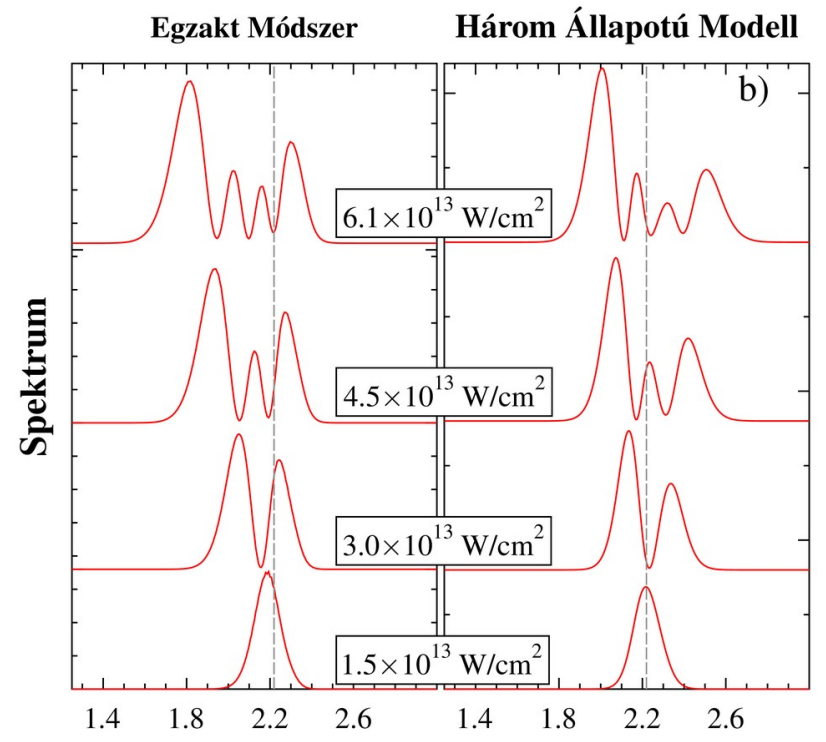

Elektron Energia (eV) Elektron Energia (eV)

2.ábra Intenzív lézerpulzussal kiváltott $2+1$ fotonos rezonancia-fokozott ionizáció. (a) A lézer intenzitásának növelésével a rendszer egyre több Rabi-oszcillációt végez, miközben folyamatosan ionizálódik. A függőleges vonalak a b) panelen alkalmazott $\mathrm{I}_{0}$ értékeket jelölik. (b) Az egész számú Rabi-oszcillációkhoz tartozó spektrumok egzakt propagációkból és a modell szerint számolva. A spektrum alakok kvalitatív egyezése a modell helyességét tükrözi ( $\tau=20 \mathrm{fs}, \omega=5.25 \mathrm{eV})$.

\section{Három állapotú minimális modell}

A spektrumban tapasztalt fenti megfigyelések kvalitatív értelmezéséhez célszerü bevezetni egy három állapotú minimális modellt, mely észszerü egyszerüsítések mellet megragadja a vizsgált $2+1$ fotonos REMPI folyamat fizikáját. Az [5]-ben felvázolt gondolatmenet általánosítása révén az alábbi mátrix egyenletet kapjuk a rezonánsan csatolt $\mid \mathrm{I}>$ és $\mid \mathrm{R}>$ állapotok valamint az $\mid \varepsilon>$ ion állapotok $c_{k}(t), k=I, R, \varepsilon$ populációs együtthatóira [9]:

$$
i\left[\begin{array}{c}
\dot{c_{I}} \\
\dot{c_{R}} \\
\dot{c_{\varepsilon}}
\end{array}\right]=\left[\begin{array}{cc:c}
S_{I}(t) & \Omega_{2}(t) & 0 \\
\hdashline \Omega_{2}(t) & S_{R}(t)+\Delta-i / 2 \Gamma(t) & 0 \\
\hdashline 0 & \Omega_{1}(t) & \Delta+\delta
\end{array}\right]\left[\begin{array}{c}
c_{I} \\
c_{R} \\
c_{\varepsilon}
\end{array}\right]
$$

Az (1)-ben megjelennek az időfüggő $\mathrm{S}_{\mathrm{k}}(\mathrm{t})$ Stark-eltolódások, valamint az $\Omega_{1}(t)$ egyfoton és az $\Omega_{2}(t)$ kétfoton Rabi-frekvenciák, és a $\Gamma(t)$ ionizációs ráta, mely az $\mid \mathrm{R}>$ állapot populációjának ionizáció miatt bekövetkező csökkenését írja le. Ezen mennyiségek egyaránt a pulzus burkolójának időlefolyását követik és meghatározhatók a rendszer stacionárius hullámfüggvényeinek, valamint a lézer paramétereinek segítségével. Az alkalmazott pulzusunk kétfoton rezonánsan csatolja az |I $>$ és $\mid \mathrm{R}>$ állapotokat, ezért a kétfotonos elhangolás $\Delta=0$. Végezetül pedig a $\delta$ egyfotonos elhangolás a spektrum nominális pozíciójához viszonyított energia különbséget méri a kontinumban. 
Az (1)-es egyenlet nagyon egyszerü és gyorsan megoldható (pl. Runge-Kutta módszerrel) minek eredményeképpen megkapjuk a $c_{k}(t)$ koefficiensek időfejlődését. Ezen koefficiensek pulzus utáni értékéből meghatározható az állapotok betöltöttsége az ionizáció végén. Ennek megfelelően a spektrumot az alábbi egyszerü összefüggéssel számolhatjuk a három állapotú minimális modell esetén: Spektrum $\left(\omega_{\varepsilon}\right)=\left|c_{\varepsilon}(t=\infty)\right|^{2}$, ahol $\omega_{\varepsilon}=\omega_{\varepsilon_{0}}+\delta$ a kilépő elektronok energiája $\left(\omega_{\varepsilon_{0}}=3 \omega-I_{p}\right.$ a nominális spektrum pozíció).

Az (1)-es egyenlet megoldása révén kapott fotoelektron spektrumok a 2.ábra b) panelének jobb oldalán láthatók ugyanazon lézer pulzus paraméterek esetén mint a panel bal oldalán ábrázolt egzakt spektrumok. A két különböző módon számolt spektrum alakjának kvalitatív egyezése arra enged következtetni, hogy a modell megfelelően írja le a vizsgált folyamatot. Ez lehetőséget ad a spektrumalak értelmezésére.

\section{3. Értelmezés}

Az egzakt és modell spektrumok kvalitatív egyezésének köszönhetően (2.ábra(b)) az (1)-es egyenlet felhasználható a spektrum alakjának értelmezésére. Az (1)-ben pirossal bekeretezett $2 \times 2$-es almátrix írja le az $\mid \mathrm{I}>$ és $\mid \mathrm{R}>$ állapotok rezonáns lézerpulzus által kiváltott dinamikáját. A lézer erős csatolása révén két véges élettartamú rezonancia állapot alakul ki, melyek energiái időtől függőek és a fenti 2x2-es mátrix sajátértékeiként állnak elő [5,9]. A 2x2-es almátrix diagonalizációjával kapott rezonancia állapoti energiákat a 3.ábra b) panelén láthatjuk a nominális pozícióhoz viszonyítva (piros és kék görbék). Ezen energia görbék a kontinumban közvetlenül tükrözik az emittált
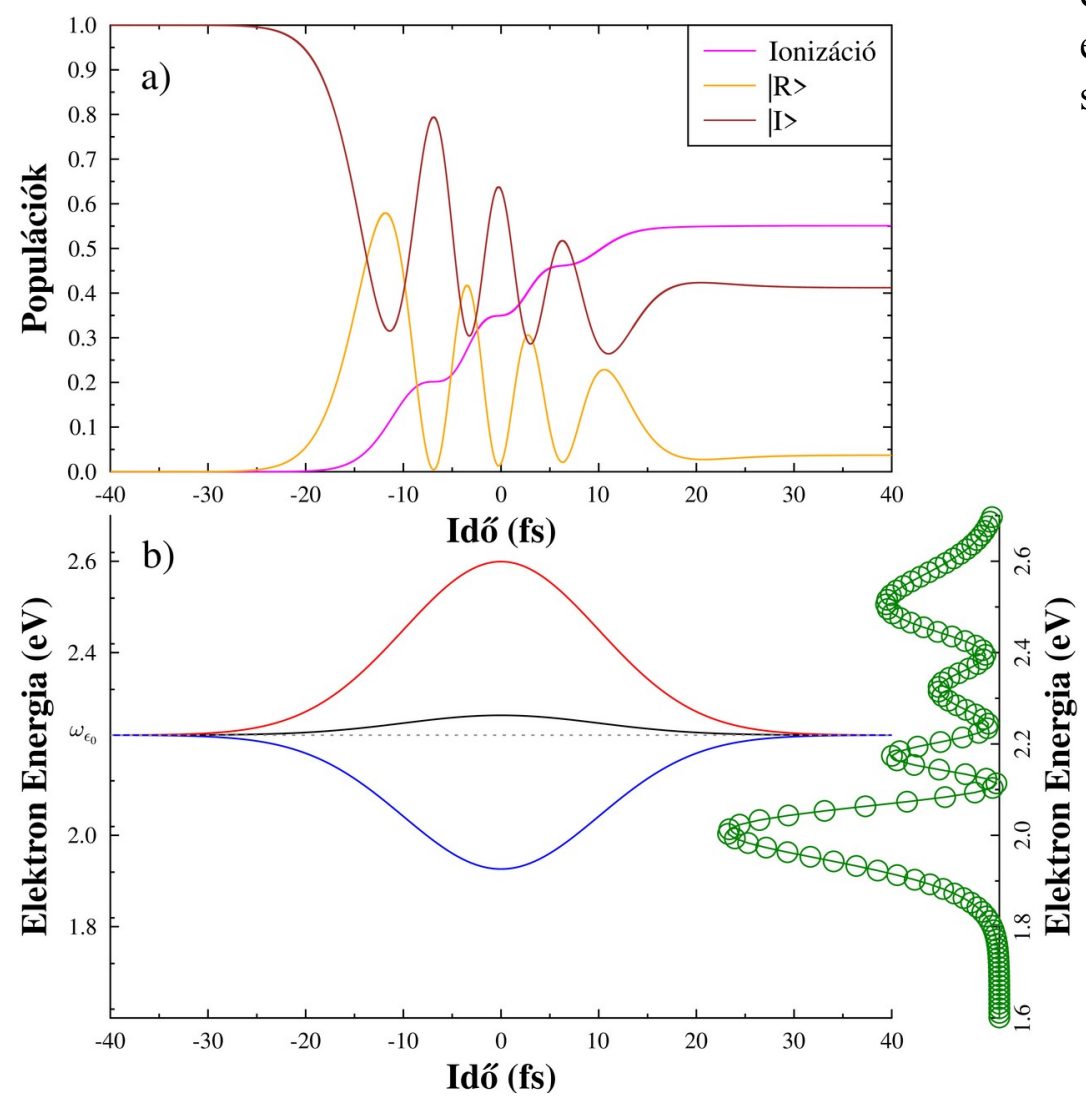

elektronok energia eloszlását, ezáltal pedig a spektrum várható szélességét, eltolódását és alakját. 3.ábra (a) A 2+1 fotonos REMPI folyamatban az $\mid \mathrm{I}>$ és | $\mathrm{R}>$ állapotok betöltöttségei. (b) A rezonáns csatolás során kialakuló véges élettartamú rezonancia állapotok időfüggő energiái (piros és kék görbe) taszítják egymást követve a pulzus burkolóját. Ezen energiák felelősek a kilépő elektronok spektrumának (zöld görbe) alakjáért (részletek a szövegben).(lézerparaméterek: $\tau=20 \mathrm{fs}, \omega=5.25 \mathrm{eV}$, $I_{0}=6.1 \times 10^{13} \mathrm{~W} / \mathrm{cm}^{2}$.) 
A pulzus felszálló ágában a rezonancia állapotok taszítják egymást, a leszálló ágban pedig újra közel kerülnek egymáshoz. Az eközben kilépő elektronok ezáltal egy széles energia tartományban emittálódnak (innen a spektrum kiszélesedése), továbbá a szétnyílás középvonala (folytonos fekete vonal) a nominális pozícióhoz képest eltérül (innen a spektrum eltolódása). Mindeközben a rendszer több Rabi-oszcillációt végez és az ionizáció ennek megfelelően adagokban következik be (3.ábra(a)). A pulzus felszálló ágában emittált elektronok pontosan ugyanakkora energiával rendelkeznek mint a leszálló ágban kilépök, ezáltal az időkésleltetés miatt a spektrumban interferenciát eredményeznek. A mintázatban megjelenő csúcsok száma pontosan tükrözi a rendszer által végzett Rabi-oszcillációk számát.

A spektrum aszimmetriája a rezonancia állapoti energiák eltérő nagyságával magyarázható. A nagyobb energiájú rezonancia állapot energiája távolabb esik a nominális pozíciótól mint az alacsonyabbé, ezáltal a piros görbe görbülete nagyobb mint a kék görbéé a pulzus maximumának pillanatában amikor a legvalószínúbb az ionizáció. Következésképpen a felső ágban (piros görbe) kilépő elektronok egy szélesebb energia tartományt ölelnek fel és itt a spektrum emiatt alacsonyabb, ellenben az alsó ágon (kék görbe) kilépő elektronok keskenyebb energia sávban oszlanak el és ezért ott a spektrum magasabb.

A dolgozatban bemutatott modell jól leírja a spektrum fỏbb jellemzőit, azonban a spektrum eltolódásában eltéréseket találunk az egzakt esethez képest. Ennek feloldása a kontinum állapotok Stark-eltolódásának (ponderomotív energia) figyelembe vételével tehető meg a későbbiekben, minekután a modell kvantitatív analízisre is alkalmassá válik.

\section{Köszönetnyilvánítás}

A kutatást az EFOP-3.6.2-16-2017-00005 azonosítójú, EU társfinanszírozású projekt támogatta.

\section{Irodalom}

[1] K. Toyota, O.I. Tolstikhin, T. Morishita, S. Watanabe, Phys. Rev. A 76, 043418 (2007) https://doi.org/10.1103/PhysRevA.76.043418

[2] P.V. Demekhin and L.S. Cederbaum, Phys. Rev. Lett. 108, 253001 (2012) https://doi.org/10.1103/PhysRevLett.108.253001

[3] M. Baghery, U. Saalmann, J.M. Rost, Phys. Rev. Lett. 118, 143202 (2017) https://doi.org/10.1103/PhysRevLett.118.143202

[4] W.C. Jiang and J. Burgdörfer, Optics Express 26, 19921 (2018) https://doi.org/10.1364/OE.26.019921

[5] P.V. Demekhin and L.S. Cederbaum, Phys. Rev. A 86, 063412 (2012)

https://doi.org/10.1103/PhysRevA.86.063412

[6] A.D. Müller, E. Kutscher, A.N. Artemyev, L.S. Cederbaum, P.V. Demekhin, Chem. Phys. 509, 145 (2018)

https://doi.org/10.1016/j.chemphys.2017.10.004

[7] A.A. Silaev, M.Yu. Ryabikin, N.V. Vvedenskii, Phys. Rev. A 82, 033416 (2010)

https://doi.org/10.1103/PhysRevA.82.033416 
[8] C.M. Dion, A. Hashemloo, G. Rahali, Comput. Phys. Comm. 185, 407 (2014) https://doi.org/10.1016/j.cpc.2013.09.012

[9] A. Tóth, A. Csehi, publikálás alatt (2020) 